\title{
CHAPTER 1 \\ GREEN TOURISM AS A PERSPECTIVE DIRECTION FOR RURAL ENTREPRENEURSHIP DEVELOPMENT
}

\section{Boiko V. O.}

\section{INTRODUCTION}

The current state of market transformation of the Ukrainian economy requires the search for new forms of economic management in rural areas. One such form can be small business, as it maximizes the interests of manufacturers and consumers of products. In addition, all segments of people, especially rural, are interested in the development of this sector of the economy. Because it becomes the basis for the formation of the modern economic system of the country by providing employment to a large part of the population. Rural green tourism is a promising manifestation of entrepreneurial activity in rural areas. The development of green tourism is a proven world practice as a way of raising the incomes of rural people. There is currently no systemic national policy in this area in Ukraine. It is necessary to make extensive use of the European practice and to create the necessary legislative environment as soon as possible to overcome the problems hampering the development of rural green tourism based on personal husbandries and farm enterprises. According to statistics, $35 \%$ of residents of the EU cities prefer a holiday in rural areas. One third go there because of the busy rhythm of city life, $20 \%$ combine holidays with active self-guided travels, the dame amount of people just wants to spend time outdoors. Rural tourism has been around for over half a century. Alsace in the south of France is considered to be its place of origin. In the early 1950s, many farmers began to travel to cities because of losses in agriculture. To stop the migration, the French government proposed to arrange farms for receiving tourists. And in the 1970s rural tourism gained its own status. Now it brings in 1 billion USD profits to the state budget of France and 3 billion USD to the regional budgets.

Rural tourism is also popular in Austria, England, Germany, Italy and Spain. In 1992, the EU reformed its Common Agricultural Policy and started targeted funding of the sphere, in particular, for rural road construction. After all, according to EBRD experts, for people born in a countryside, their accommodation in a city is 20 times more expensive 
than creating the conditions for their life and work in the village. It is also estimated that the income from one place of accommodation is equivalent to the income a farmer brings per one cow per year ${ }^{1}$. Rural green tourism is a form of business activity, it can be attributed to the field of small business, which forms the market environment in the domestic agro-industrial complex. Its development contributes to the creation of new jobs in the countryside, the introduction of scientific and technological progress in small forms of agricultural production, it is an important source of formation of local budgets and budgets of peasants. They become a buffer zone that reduces the risk of destruction of the potential of large-scale agricultural production ${ }^{2}$. The development of rural tourism as a new form of entrepreneurial activity requires substantiation of many aspects, which should promote further development and ensure a proper level of competition, which is especially important in market conditions. Therefore, the main task of the article is to study the general concept of the «green» economy, to consider the features of rural tourism in the southern region and to identify factors that have a negative impact on its development.

\section{1. «Green» economy as an innovative direction in world economic activity}

Over the past three decades, humanity made significant progress in improving material well-being. But this progress was made at the cost of deteriorating the planet's natural environment. Continuing economic development without significant change of the current economic model will lead to increase of environmental threats and make sustainable development impossible. Taking this into consideration, economists, sociologists, politicians, representatives of the natural sciences and business begun to look for new paths of development that can restore the natural environment while ensuring a decent standard of living for the population. One of the results of this search was the concept of the «green» economy, which, with the support of international organizations and national governments, gained considerable popularity.

The term «green» economy was first introduced in 1989 in a report prepared by a group of environmental economists for the United

\footnotetext{
${ }^{1}$ Kak ES pomogaet razvivat «zelenyiy» turizm v Ukraine [How the EU helps to develop green tourism in Ukraine]. URL: https://news. finance. ua/ru/ news-/285915/kak-es-pomogaet-razvivat-zelenyjturizm-v-ukraine

${ }^{2}$ Korobka S.V. (2011). Zelenyi turyzm yak riznovyd pidpryiemnytskoi diialnosti v silskii mistsevosti [Green tourism as a type of entrepreneurial activity in rural areas]. Visnyk Chernivetskoho torhovelnoekonomichnoho instytutu. Vypusk II (42). Chastyna I. URL: http://tourlib.net/statti_ukr/korobka2.htm
} 
Kingdom Government in the framework of consultations on sustainable development and its measurement ${ }^{3}$.

The concept of a «green economy» has become particularly important in recent years. It is widely discussed not only by economists, but also by politicians in the context of sustainable development and poverty eradication, backwardness and starvation. The engine of the process of globalization is modernization and transition of the world economy, especially of the industrial countries, to a new technological institution, which, together with a qualitative updating of the technological base, improving the efficiency of production and competitiveness of the economy, is intended to ensure the improvement of quality of life and living environment. Abroad, the transition is being implemented by the «green» growth economic policy formally adopted by the Organization for Economic Co-operation and Development (OECD) in 2009 as a strategic direction for the development of all its members for the long (up to 2030) and more distant (up to 2050) perspective.

The rational use of scarce natural resources on the planet and the reduction of the dependence of the economy on traditional fossil energy sources, which have a negative impact on climate change and cause energy vulnerability in many countries, are fundamental factors for the survival of socio-economic systems in the 21 st century ${ }^{4}$.

According to scientists, in 30 years the world's population will increase by about $30 \%$ to 9 billion people in 2050 compared to the current 7 billion people, with $98 \%$ of it will live in developing countries and new independent states. The population of cities will double, the ratio of the middle class will increase. People aged 65 and over will account for about $20 \%$ of the world's population as a result of aging. To provide the planet's growing population with food and energy, an increase in agricultural productivity of an average of $2 \%$ per year is required. Today, the agricultural sector consumes over $70 \%$ of the world's drinking water resources through traditional tillage technologies and is responsible for $13 \%$ of the world's greenhouse gas emissions. The population is expected to generate more than 13.1 billion tonnes of waste in 2050 due to rising living standards and incomes. This is $20 \%$ more

3 Pearce D. Markandya A., Barbier E. Blueprint for a green economy. London : Earthscan Publications ltd, 1989. 193 p. [UK pound]6.95. ISBN 185383066 6.: Blueprint 2: Greening the Worl, Ecological Economics, Elsevier, vol. 7(1), pages 75-78, February. URL: https://ideas.repec.org/a/eee/ecolec/v7y1993i1p75-78.html.

${ }^{4}$ Musina L. Stan i perspektyvy rozvytku zelenoi ekonomiky ta zelenoho biznesu v Ukraini [State and prospects of development of green economy and green business in Ukraine]. Analitychna dopovid. URL: http://eep.org.ua 
than in 2019, despite the fact that only $25 \%$ of all waste today is disposed or recovered. Global energy demand will increase by $36 \%$ during 2018-2035 .

In view of this global challenge, international organizations and the business community are working to improve the structure of the economy and the models of production and consumption of resources to transfer global growth into more sustainable rails. Particular attention is paid to the following studies:

implementation of new resource-efficient and cleaner technologies;

finding solutions to climate change;

increasing the efficiency of agriculture and forestry;

urban and infrastructure refresh;

correction of human values and behavior towards sustainability.

The global financial crisis at the end of the last decade has cast doubt on people's beliefs in business and government action, and has stepped up the search for answers to many complex issues in society. These include how to measure success and progress, how to decouple economic growth from resource consumption and ecosystem degradation, and tap into new sources of growth related to the use of resource-efficient and eco-friendly technologies and innovations.

Core of such pursuits is the development and refinement of the concept of sustainability that binds the well-being of the present and future generations: meeting the needs of the modern age should not undermine the ability of future generations to meet their own needs.

Accordingly, the implementation of the «green» economy to achieve sustainable development principles has several main directions:

1) direction of «inexhaustible resources»: renewable energy resources; recycling of materials; organic agriculture that consumes the least energy, does not use artificial means of protection and nutrition of plants, GMO;

2) optimization direction: energy efficiency of production and housing; reduction of using cars; reduction of products energy value; reduction of water consumption; restoration of forests and conservation areas;

3) social direction: the principle of equality in the allocation of scarce resources; solving land allocation and land use planning; a

\footnotetext{
${ }^{5}$ Berezhna Yu.S. (2012). Kontseptsiia «zelenoi ekonomiky»: mizhnarodnyi aspekt [Green economy concept: an international aspect]. Uchenyie zapiski Tavricheskogo natsionalnogo universiteta im. V.I. Vernadskogo, no. 1, pp. 210-215.
} 
financial regulation system that guarantees the basic needs of most people;

4) managerial direction: changing the measurement value of wealth and the success of states, which means that GDP should be complemented by indicators of natural services and biodiversity conservation; a global security system with interventions in developing countries; investment in institutionalism, optimization of management and decision-making.

It is important to emphasize that the concept of the «green» economy does not replace the concept of sustainability, but develops it and is a means of its practical implementation. «Green» development can only be ensured if environmental and economic policies are integrated in such a way that social progress, economic growth and the improvement of the quality of life of the population occur against the backdrop of reducing threats to the environment ${ }^{6}$.

The transition to the «green» economy is based on innovative solutions, in particular, on radical changes in the social sphere. Social innovation is connected with the formation of public awareness, modernization of education and employment. Awareness and understanding of the complexities of global economic, environmental and social issues, as well as new opportunities, are prerequisites for defining priorities and behavior and require a focused policy to shape a modern worldview.

Taking into account the above approaches and combining them with the aforementioned goals of the "green" economy, we can conclude that it is advisable to highlight the following 10 basic principles of the "green" economy.

1. Orientation to the future: taking into account the consequences of economic activity for the existence of future generations.

2. Measurability and comparability: creation of an open system of national and international reports on the level of economic and social development of territories and their impact on the environment, development of adequate indicators of social development assessment that would take into account the environmental component.

3. Sustainable production and consumption: a reorientation from traditional standards and production and consumption patterns to the newest «green».

\footnotetext{
${ }^{6}$ Halushkina T.P. (2012). «Zelena» ekonomika v sektoralnii modeli rozvytku Ukrainy [Green economy in the sectoral model of development of Ukraine]. Ekonomichni innovatsii, no. 48. URL: http://archive.nbuv.gov.ua
} 
4. Social development: increasing the employment rate of the population in the "green" sectors of the economy, improving the quality of life through increasing incomes and access to better resources, ensuring the right of citizens to personal development.

5. Public cooperation: involving the broad public, business, governmental institutions, international and non-governmental organizations in joint actions to shape the «green» economy.

6. Resource efficiency: increasing the level of resource efficiency, recycling and increasing the economic impact of reducing negative environmental impacts.

7. Environmenal friendliness: reduction of negative anthropogenic impact on the environment, in particular, of emissions of greenhouse gases, solid waste, pollution of water bodies and land, preservation of biodiversity and environmental protection, introduction of environmental education of the population.

8. Cost-effectiveness: the ongoing costs of implementing green standards should not be a constraint on economic development, but should help to create the basis for the long-term development.

9. Comprehensive implementation of the «green» economy principles at all levels of government and in all areas of activity.

10. Equality and equity: equal access and equitable distribution of natural resources. These principles reflect the most important aspects of the «green» economy within the concept of sustainability ${ }^{7}$.

Greening the economy, seen as a way to foster economic progress while ensuring environmental sustainability and social equality, is recognized as a promising path for sustainability. For this reason, the UN and its Member States are working to embrace green economy approaches in their instruments, including the 2030 Agenda for Sustainable Development and the Sustainable Development Goals (SDG).

The «Environment for Europe» process began with the First PanEuropean Conference of Ministers of the Environment in Dobris Castle in June 1991.

At the Seventh Conference on «Environment for Europe» held in Astana, Kazakhstan in 2011, ministers of the environment decided to promote the transition to the «green» economy. They stressed the need to step up efforts to reduce economic growth from environmental

\footnotetext{
${ }^{7}$ Chmyr O.S., Zakharkevych N.P. (2013). «Zelena» ekonomika: sutnist, tsili ta bazovi pryntsypy [Green economy: the essence, goals and basic principles]. Ekonomichnyi visnyk Donbasu, no. 3 (33), pp. 54-62.
} 
degradation by stimulating green investment and innovation, promoting sustainable production, improving energy and resource efficiency. They also stressed the importance of developing the human, institutional and economic capacity to support the greening of the economy, in particular through research, education and training of specilaists.

The Eighth Conference of Ministers «Environment for Europe», held in 2016 in Batumi, Georgia, advanced the process of transition to the «green» economy in the region in response to the commitments made in Astana and focused on the question of how to begin this process. The intention is to support the Ministries of the Environment in launching and promoting discussions on the «green» economy in the governments of the European countries and in other relevant forums and in promoting the agenda for the «green» economy.

The Pan-European Green Economy Strategic Framework was endorsed at the Conference. The strategic framework provides the panEuropean region to implement a model of development that would ensure economic progress, social justice and the sustainable use of ecosystems and natural resources in order to meet the needs of the present generation without compromising the ability of future generations to meet their needs. The «green» economy, as one of the approaches to reorienting consumer habits, investments and trade in support of the inclusive «green» economy aimed at overall prosperity, is one of the promising ways to achieve sustainability goals in the region and beyond.

Greening the economy in the Pan-European region will achieve three main objectives:

Reduction of environmental risks and scarcity of natural resources;

Strengthening economic progress;

Improving human well-being and strengthening social justice.

Achieving these three objectives will foster prosperity through economic progress, ensuring environmental sustainability and social inclusivity. This can be achieved by stimulating and encouraging investment and trade to support such economic progress that would ensure greater fairness and not be accompanied by environmental degradation. In addition, to achieve this, consumers need to be stimulated to change their habits so as to prevent excessive consumption and bring to the fore the green goods and services. Supporting natural capital, ecosystems and related services in this way will improve the quality of life and promote overall prosperity, while 
decreasing environmental load will reduce human health risks and increase well-being ${ }^{8}$.

\subsection{Current trends in green tourism development in the Southern region}

In Ukraine, there are all the prerequisites for the development of rural recreation, which can be seen as a specific form of ancillary economic activity in rural areas using the natural and cultural potential of the region, or as a form of small business that allows to solve to some extent the problem of employment of rural population, to improve its well-being, to make fuller use of the natural and historical and cultural potential of the countryside. The case of rural recreation development has a real state perspective and contributes to improving the socioeconomic situation of rural areas.

Rural tourism helps residents to solve a number of social and economic problems: the on-site realization of agricultural products and increase the employment of rural population in many areas of the economy: in the hotel business, communications, banking, transport. That is, it is the area where the multiplier effect is most clearly manifested. Its development will greatly benefit agriculture, construction, culture, local crafts, etc ${ }^{9}$.

The development of rural green tourism encourages the improvement of rural estates, streets, villages as a whole, and stimulates the development of social infrastructure. A significant role is played by the development of rural green tourism in raising the cultural and educational level of the rural population. Preparing to receive and serve vacationers, members of peasant families are involuntarily forced to update their knowledge of housekeeping, hygiene and sanitation, cooking, etc., communication with guests extends their horizons, allows to make new acquaintances, to strike up new friends in different locations ${ }^{10}$.

In the course of decentralization in the territory of the ATC (amalgamated territorial community), a special need for the activities of the local population, other than large agricultural production, arose for

\footnotetext{
8 «Zelena» ekonomika - novyi hlobalnyi napriamok rozvytku [Green economy is a new global development area]. URL: http://ecoosvita.org.ua/storinka-knygy/zelena-ekonomika

9 Zakharchenko O.V. (2014). Perspektyvy rozvytku silskoho turyzmu [Rural tourism development prospects.]. Zbirnyk naukovykh prats Tavriiskoho derzhavnoho ahrotekhnolohichnoho universytetu (ekonomichni nauky), no. 4(28), pp. 97-100.

${ }^{10}$ Stepanov V.Iu. (2018). Silskyi zelenyi turyzm v Ukraini: problemy ta perspektyvy [Rural green tourism in Ukraine: problems and prospects]. Aktualni problemy derzhavnoho upravlinnia, no. 1(53), pp. 1-5.
} 
the sustainability. Citizens, in turn, seek to relax in recreational areas devoid of urbanism.

Rural tourism in Europe went the way of developing niche services. A citizen client can choose a farm for a specialty visit: winemaking, beekeeping, cheesemaking, poultry farming, horse breeding and more. To identify the features of the services, graphics have been developed that accompany the sites of the farms, and logo-identifiers carry stylized images of a form of recreation, for different preferences.

In Ukraine, the main operating model is a family farm based on a personal peasant farm. The requirements for such farms are clearly defined and spelled out. The main requirement for the location of the guests in the farmstead is the comfort that the locals are accustomed to: modern (albeit stylized) furniture and bathroom accessories, the Internet, the appropriate sanitary level.

For appartment buildings, estates are divided into two basic types. The first is an outwardly one hundred percent authentic modern building. The second is a modern house of original architecture. An important feature of a farmstead is a place where the guest can retire or spend time with his/her family, free from the owners' attention. There are many methods of its realization: gazebobraided from the vine, lakes with islands, on which there are some bizarre huts, etc. The psychological readiness of the whole farmer family to welcome strangers into their yard is very important ${ }^{11}$.

The dynamics of the transformations taking place in Ukraine require fundamentally new approaches to planning the development of all branches of the Kherson region, and even more so for those recognized as priorities in the region. Significant industries include tourism. It is the construction of the tourism development strategy, initiated by the Department of Culture and Tourism of the Kherson Regional State Administration, which is the basis for creating the conditions for transition of the industry to the state of competitiveness in the Ukrainian tourist market. The planning process itself is a special kind of decision making regarding the specific future of the recreation and resort complex and tourism. Action programs are sought by the community as a whole of the «triangular cooperation» (business, public movement, government, etc.) and can be comprehended even with the influence of various internal and external factors.

\footnotetext{
${ }^{11}$ Makulskyi K. Silskyi zelenyi turyzm akumuliuie prynady pryrody, tradytsii i nishevykh promysliv [Rural green tourism accumulates the charms of nature, traditions and niches]. URL: http://www.agroprofi.com.ua/statti/1713-silskyy-zelenyy-turyzm-akumulyuye-prynady-pryrody-tradytsiy-inishevykh-promysliv
} 
The Kherson region is a unique territory for tourism, rest and recreation, which has enough advantages for the formation and development of a powerful resort and tourist complex. The region has a wide access to the Dnipro main waterway, and it is the only one of the regions of Ukraine that has access to two seas simultaneously: the Black Sea and the Azov Sea. Exactly in the Kherson region there are located: Oleshkivski sands, the only natural desert in Europe, «Stanislavski Cliffs», the largest man-made forest in the world and even unique mountain landscapes in the middle of the steppe .

The region has: 12 resorts; more than $450 \mathrm{~km}$ of sea coastline; $200 \mathrm{~km}$ of which are equipped with sand beaches; the «Arabatska Arrow», the longest sandbar in the world; more than 70 deposits of healing balneal resources (mineral and thermal waters, therapeutic muds, brine of the lakes), among which is the unique Lemuriiske Lake, the medical mud of which has been tested, certified and approved for use as a therapeutic and cosmetic product. Skadovsk is a resort of national standing, a center for children's health and recreation.

There are 80 objects of national, international and local importance in the territory of the region. Of the four biosphere reserves of Ukraine, two are located in the Kherson region. These are the Black Sea biosphere reserve and Askaniia-Nova, which are part of the UNESCO World Network of Biosphere Reserves. The real tourist pearls of the region are the national nature parks: Azov-Syvash, Oleshkivsky Sands, Dzharylhatskyi, Nyzhniodniprovskyi and the recently created Kamianska Sich.

In Kherson region, green tourism is gaining momentum, with $70 \%$ of the population living in the city. Therefore, rural holidays are attracting more and more locals who choose not to spend on expensive comfortable hotels, but a budget farmstead with national colors. The Kherson region has huge potential for the development of rural green tourism. There are 49 rural green tourism estates in the region. Due to the development of rural green tourism, material well-being is increasing and the employment problems of the rural population are partially solving ${ }^{12}$.

An important prospect for rural green tourism development is the expansion of opportunities to sell personal ancillary products on site not as agricultural raw materials, but as finished products after proper processing and preparation. Farmsteads that take holidaygoers are also

\footnotetext{
${ }^{12}$ Boiko V. (2016). Algorithm of developing competitive strategies and the trends of realizing them for agricultural enterprises. ScienceRise. T. 2, N 1 (19), 30-34. DOI: 10.15587/2313-8416.2016.60349. [in Ukrainian]
} 
improving the structure of crops in the backyard, taking into account the needs of guests, expanding the range of vegetables, fruit trees, berries, etc.; develop and diversify farm animals, plant a greenhouse.

In its functions, preparing and meeting guests cannot be a banal and mechanical procedure. Namely: provision of the room fund ready for reception of guests, its cleanliness control, support of the electricity and water supply systems functioning, conditioning, arrangement of the territory, provision of food culture, provision of thematic information and cognitive, cultural, animation space, function of operational assistance (in emergency cases: the need for medical care, fire safety, law enforcement, etc.). Not only the landlady and the landlord are involved, but also other residents of the estate, including teenagers and children. Each is assigned a specific function, which is performed according to internal instructions, but with creativity and enthusiasm.

Thus, the study of the phases of the rural tourism guest cycle revealed important aspects of the hosts' interaction with potential clients and allowed to create a new vision of hospitality as an element of their own business, built on the systematic ability to work in the tourism market qualitatively.

Annually, in April-May, within the framework of the International Tourism Forum «The Kherson region - rest, treatment, trips in the Tavriia ecological conditions» meetings of sections «Rural green tourism as a promising direction of village revival» are held, which present the potential of rural territories of the Kherson region in the sphere of green tourism.

The decision of the Kherson regional council № 1095 dated December 14, 2018 approved the regional program «Development of tourism and resorts in the Kherson region» for the period of 2019-2021, which provides measures to support rural green and agritourism, in particular:

- promotion of certification of estates and green tourism bases (certificates of conformity of services for accommodation and food);

- conducting professional and counseling events with the participation of profile associations on the promotion of recreation in rural areas in the Kherson region, the issuance of annual specialized catalogs, media coverage;

- formation of tourist stay programs at the territory of the region at any time of the year.

In addition, an agricultural service cooperative «Zacharovanyi sad» of fruit and berry type was created in the territory of the region in the 
Holopristansky district in 2018, one of its activities is the organization of various types of recreation and entertainment.

The Kherson region for some time positioned itself as the largest fruit and vegetable area of Ukraine. It is now concluded that rural tourism is perhaps the only sustainable development path beyond largescale agricultural production. The area is heavily plowed and at the same time has a very high percentage of protected natural lands, compared to other regions of the country: $13 \%$ of the territory. But there are no objects of excessive tourist attraction.

As an anchor idea, the historical component was chosen here: «the wild field» and «the milky way». Despite the historical name of «the wild field», this place has always been inhabited by people. In addition, there were trade routes to the salt fields on the floodplain of the Azov Sea - Syvash, and on the Black Sea - near the Dnipro river mouth of the settlement Prohnoiska Palanka (now the village Heroiske).

The chumaks' way through the wild field began in the town of Beryslav, where there was a crossing through the Dnipro river. Further, the salt road was divided: to Syvash to the South-East, and to Prohnoiska Palanka to the South-West. The organizers of the project «Salt Way» connected the route: from Kherson tourists go to Beryslav, then to Syvash, from there to Heroiske and again to Kherson. Along the route, tourists visit villages with facilities that attract local villagers to serve guests. There are stopping points with high comfort and prices, as well as moderate comfort and appropriate prices.

An example of a high price level is the village of Kozatske. There are natural objects: waterfalls in the steppes near the ruins of Prince Trubetskoi's palace. Anchor object is the «Trubetskoi's Chateau»: an original ancient building of aristocrats country house with wine production. The restored complex has a hotel, restaurant, wine cellars. An example of a moderately priced object is the village of Hryhorivka with 40 farmsteads of different agricultural activities. Tourists can go the entire route or visit selected sites. An example of the project «Salt Way» demonstrates how rural green tourism helps to implement sustainable rural development policies ${ }^{13}$.

The Kherson region gained the glory of Ukraine's breadbasket long time ago, but the southern region specializes not only in cereals and fruit

\footnotetext{
${ }^{13}$ Makulskyi K. Silskyi zelenyi turyzm akumuliuie prynady pryrody, tradytsii i nishevykh promysliv [Rural green tourism accumulates the charms of nature, traditions and niches]. URL: http://www.agroprofi.com.ua/statti/1713-silskyy-zelenyy-turyzm-akumulyuye-prynady-pryrody-tradytsiy-inishevykh-promysliv
} 
and vegetables, the region has considerable potential in the field of viticulture and winemaking. In terms of climate or soil, the Kherson region is not inferior to the world-famous wine provinces: French Bordeaux or Northern and Central Italy. The lower Dnipro zone is ideal for growing sunberry.

The European practice shows that family wineries are an effective legal form of business in the gastronomy. In Ukraine, throughout the reform period, family-type wineries have not expanded since the formation of optimal vineyard areas and the creation of a wine production base require considerable financial resources.

The first family-owned winery in Ukraine was established in the Kherson region on the basis of the farm of «Kurin», headed by Mykola Khalupenko. Vineyards cover 40 hectares, and his own winery produces 60,000 bottles of wine a year.

The farmer does not involve foreign experts in the work, the reason is the desire to make authentic wine and demonstrate the benefits of a domestic product. For the season, the chateau processes 30-50 tonnes of grapes, $85 \%$ of the produce is dry wines, but the uniqueness of the muscat chateau will surprise any expert with a bouquet of aromas. There are 53 wooden barrels of 200, 250 and 500 liters in the wine cellar. Their wines are aged for two years. Ordinary wines are stored in metal barrels. Since 2011, the owner has laid the best dessert wines in the collection. The floral aroma of white dry wines and fruity shades of rose wine are noticable when wine tasting. The enterprise actively develops the direction of gastronomy, cooperating with tourist operators of the south of Ukraine. Many tour companies during the excursion to the Kherson region (on the pink lakes, geysers, sea coast, to the Askaniia-Nova Reserve) visit the «Kurin» winery as part of the tour. More than 50 tastings were held in 2019, which certainly help to expand the market and increase the number of wine connoisseurs ${ }^{14}$.

The agrarian complex of the region is the basis of stable development of the Kherson region, and it is not only production, but also the development of rural territories, employment and as a consequence, improving the standard of living ${ }^{15}$. The Kherson region is

14 Avercheva N.O., Boiko V.O., Boiko L.O. (2019). Ekonomichna otsinka potentsialu haluzi vynohradarstva rehionu [Economic evaluation of the potential of viniculture industry of the region]. Ekonomika APK, no. 6, pp. 15-25. DOI: https://doi.org/10.32317/2221-1055.20190615 [in Ukrainian]

${ }^{15}$ Boiko V. (2017). Determinants of development of small and medium enterprises in the region of Kherson [Electronic resource]. Agricultural and Resource Economics: International Scientific E-Journal. Vol. 3. No. 2. P. 22-29. URL: www.are-journal.com 
eco-friendly, investment-friendly and open to cooperation with the inexhaustible natural and human resources.

In the tourist market, the region has a number of significant competitive advantages that must be harmoniously used in the development steps of the recreation and resort complex. It includes the historical and multinational resource of the «steppe» and sub-Dnipro regions, which are insufficiently developed today for the «seaside» sector, the opportunities of the Black Sea and the Azov sea coast, a factor of ecological consciousness of the modern tourist, culinary and wine-making «zets» traditions are so distinctive for the local traditions of hospitality.

The vision of the future of the Kherson region in view of the development of the tourist and recreational complex has the following wording: "The Kherson region is the center of the Ukrainian Black Sea region, the edge of two seas, unique multinational steppe culture, ecological cleanliness and high quality of life and hospitality of the residents». Thus, it is possible to formulate the mission of the tourist and recreational complex of Kherson region: «By way of the introduction of high standards of hospitality in tourism institutions of the Kherson region to improving the quality of life of residents» ${ }^{16}$.

The performance of SWOT-analysis for the weaknesses and strengths of the region for the tourism industry has identified the following trends. Among the strengths are the geographical location, holding festivals, fairs, traditions of melons, winemaking, vegetable growing, the presence of reserves, wetlands, national and international nature parks, the availability of medicinal water, brine and mud. In addition, rural tourism does not require large startup capital, is based on a sustainability model with favorable market conditions.

Among the weaknesses, the greatest importance is attached to the lack of image of Kherson region in the world as an area of interest for recreation and rest, neglected state of communal infrastructure, lack of compliance of tourist establishments with international standards, low qualification of personnel, lack of systematic information support to the industry, insignificant investments in industry and of the well-defined strategy of development of green and rural tourism in Ukraine.

The analysis of weaknesses and strengths created the prerequisites for determining the direction of efforts in the field of development. The

\footnotetext{
${ }^{16}$ Kravets O. Silskyi turyzm - tradytsii hostynnosti, yaki prynosiat prybutok [Rural tourism - profitmaking hospitality traditions]. URL: http://artkavun.kherson.ua/uaslskij_turizm_tradits_ gostinnost_jak_prinosjat_pributok.htm
} 
following trahectories were proposed: creation of the image of the Kherson region as a European tourism center, rational use of tourist resources, extension of the tourist season, inter-municipal interaction, cooperation of communities that have tourist attractions and infrastructure, which would contribute to the long-term retention of tourists in their territory: to entertain, intrigue, surprise. Deployment of directions of tourist-recreational complex development causes creation of a coherent system of strategic and operational goals for fulfilling the mission of the region in the tourism industry.

Thus, the systematic approach and elaboration of the expert and partner model of development of the tourist and recreational complex of the Kherson region allow to present at the state level a «living» holistic concept, with specific planning and vision of the direction of movement, which is the most important stage of becoming a priority for the field of economy.

\section{CONCLUSIONS}

Based on the analysis, it is established that there is a tendency to conserve natural resources all over the world. The «green» economy, as a field in economic science, has begun active development, introducing alternative means of preserving natural resources. A similar trend is observed in Ukraine, but it has a weak development, which is due to a greater extent to economic problems and lack of funding.

Current trends on Earth have no signs of sustainability, and traditional responses to these problems usually depend on the type of economic growth that is strongly associated with the additional consumption of resources. Therefore, the development of the «green» economy should involve a revision of the standards of life of society in order to preserve the natural environment, increase resource efficiency and a phased approach to production, technological, socio-economic and natural-geographical specificities of regions and countries.

The green tourism is a strategic initiative that can make a significant contribution to the economic growth and quality of life of rural residents. However, there is an awareness that tourism must be sustainable in its development and responsible to society and the environment. In the coming years, the Ukrainian village is able to create a system of worldclass tourism services, without losing its identity and diversity of national cultures. Urban residents make up more than half of Ukraine's population, and this is a huge potential for generating demand for rural «green tourism» services. 
Analysis of the prerequisites and trends of tourism development in the Kherson region shows that the region has significant opportunities to enter the most developed regions of Europe in terms of tourism: favorable geopolitical location, comfortable microclimatic conditions, diverse landscape, unique flora and fauna, historical and architectural heritage, developed transportation network, sufficient human, material, including natural, resources.

Rural tourism is one of the most promising directions of development of the agricultural sector of the Ukrainian economy and can be an impetus for the development of small and medium-sized businesses in rural areas.

\section{SUMMARY}

The article analyzes the strategic priorities of the formation of new «green» directions of the economy and outlines the current trends of implementation of its ideology in the national dimension. The basic principles of sustainability in the implementation of the «green» economy are considered. The directions of further stages of development of the «green» economy in Ukraine are determined.

Resource potential of rural territories of the Kherson region as a prerequisite for development of green tourism in the southern region is investigated. The attention is paid to the problems of development of rural green tourism as a kind of entrepreneurial activity in rural areas. The directions of increasing the level of utilization of the tourist and recreational potential of the Kherson region have been substantiated, taking into account the need to conserve natural and anthropogenic tourist resources, improving the activity of tourism enterprises.

\section{REFERENCES:}

1. Kak ES pomogaet razvivat «zelenyiy» turizm v Ukraine [How the EU helps to develop green tourism in Ukraine]. URL: https://news. finance. ua/ru/ news-/285915/kak-es-pomogaet-razvivat-zelenyj-turizmv-ukraine

2. Korobka S.V. (2011). Zelenyi turyzm yak riznovyd pidpryiemnytskoi diialnosti v silskii mistsevosti [Green tourism as a type of entrepreneurial activity in rural areas]. Visnyk Chernivetskoho torhovelno-ekonomichnoho instytutu. Vypusk II (42). Chastyna I. URL: http://tourlib.net/statti_ukr/korobka2.htm

3. Pearce D. Markandya A., Barbier E. Blueprint for a green economy. London : Earthscan Publications ltd, 1989. 193 p. [UK pound] 
6.95. ISBN 185383066 6.: Blueprint 2: Greening the Worl, Ecological Economics, Elsevier, vol. 7(1), pages 75-78, February. URL: https://ideas.repec.org/a/eee/ecolec/v7y1993i1p75-78.html

4. Musina L. Stan i perspektyvy rozvytku zelenoi ekonomiky ta zelenoho biznesu v Ukraini [State and prospects of development of green economy and green business in Ukraine]. Analitychna dopovid. URL: http://eep.org.ua

5. Berezhna Yu.S. (2012). Kontseptsiia «zelenoi ekonomiky»: mizhnarodnyi aspekt [Green economy concept: an international aspect]. Uchenyie zapiski Tavricheskogo natsionalnogo universiteta im. V.I. Vernadskogo, no. 1, pp. 210-215.

6. Halushkina T.P. (2012). «Zelena» ekonomika v sektoralnii modeli rozvytku Ukrainy [Green economy in the sectoral model of development of Ukraine]. Ekonomichni innovatsii, no. 48. URL: http:// archive.nbuv.gov.ua

7. Chmyr O.S., Zakharkevych N.P. (2013). «Zelena» ekonomika: sutnist, tsili ta bazovi pryntsypy [Green economy: the essence, goals and basic principles]. Ekonomichnyi visnyk Donbasu, no. 3 (33), pp. 54-62.

8. «Zelena» ekonomika - novyi hlobalnyi napriamok rozvytku [Green economy is a new global development area]. URL: http://ecoosvita.org.ua/storinka-knygy/zelena-ekonomika

9. Zakharchenko O.V. (2014). Perspektyvy rozvytku silskoho turyzmu [Rural tourism development prospects.]. Zbirnyk naukovykh prats Tavriiskoho derzhavnoho ahrotekhnolohichnoho universytetu (ekonomichni nauky), no. 4(28), pp. 97-100.

10. Stepanov V.Iu. (2018). Silskyi zelenyi turyzm v Ukraini: problemy ta perspektyvy [Rural green tourism in Ukraine: problems and prospects]. Aktualni problemy derzhavnoho upravlinnia, no. 1(53), pp. 1-5.

11. Makulskyi K. Silskyi zelenyi turyzm akumuliuie prynady pryrody, tradytsii i nishevykh promysliv [Rural green tourism accumulates the charms of nature, traditions and niches]. URL: http://www.agroprofi.com.ua/statti/1713-silskyy-zelenyy-turyzmakumulyuye-prynady-pryrody-tradytsiy-i-nishevykh-promysliv

12. Boiko V. (2016). Algorithm of developing competitive strategies and the trends of realizing them for agricultural enterprises. ScienceRise. T. 2, N 1 (19), 30-34. DOI: 10.15587/23138416.2016.60349. [in Ukrainian].

13. Avercheva N.O., Boiko V.O., Boiko L.O. (2019). Ekonomichna otsinka potentsialu haluzi vynohradarstva rehionu [Economic evaluation 
of the potential of viniculture industry of the region]. Ekonomika APK, no. 6, pp. 15-25. DOI: https://doi.org/10.32317/2221-1055.20190615 [in Ukrainian].

14. Boiko V. (2017). Determinants of development of small and medium enterprises in the region of Kherson [Electronic resource]. Agricultural and Resource Economics: International Scientific E-Journal. Vol. 3. No. 2, pp. 22-29. URL: www.are-journal.com.

15. Kravets O. Silskyi turyzm - tradytsii hostynnosti, yaki prynosiat prybutok [Rural tourism - profit-making hospitality traditions]. URL: http://artkavun.kherson.ua/ua slskij_turizm_tradits_gostinnost_jak_prin osjat_pributok.htm

\section{Information about the author:} Boiko V. O.

Candidate of Economic Sciences, Associate Professor, Associate Professor at the Department of Economics and Finance, SHEI «Kherson State Agrarian University», Ukraine ORCID: https://orcid.org/0000-0002-8032-5731 